Filol. Linguíst. Port., São Paulo, v. 17, n. 2, p. 597-618, jul./dez. 2015

http://dx.doi.org/10.11606/issn.2176-9419.v17i2p597-618

\title{
Discurso jurídico e imagens
}

\author{
Law discourse and images
}

\author{
Maria Helena Cruz Pistori* \\ Pontifícia Universidade Católica de São Paulo, São Paulo, São Paulo, Brasil
}

\begin{abstract}
Resumo: Este artigo tem o objetivo de tecer consideraçôes a respeito do uso argumentativo de imagens, preferentemente fotografias, em processos judiciais das áreas penal e trabalhista. Partindo da concepção teórico-metodológica inspirada na obra de Bakhtin e do Círculo - a Análise Dialógica do Discurso, compreende cada enunciado processual como pertencente a um gênero definido da esfera ideológica do Direito e, como tal, apresentando um conteúdo temático, estilo e forma estrutural próprias; além disso, constituem-se como o projeto discursivo único do enunciador que, eventualmente, nele pode conjugar palavras e imagens na construção persuasiva do sentido. Nos enunciados apresentados, tais conjuntos verbo-visuais constituíram posicionamentos valorativos concordantes ou não, e a análise mostrou as diferentes vozes dos inúmeros discursos que circulam em nossa sociedade.
\end{abstract}

Palavras-chave: Discurso jurídico. Análise dialógica do discurso. Persuasão. Verbo-visualidade.

\begin{abstract}
This paper aims to offer some remarks upon the argumentative use of images - mainly photographs - in the legal proceedings of the criminal and labor areas. Notions and categories of dialogical discourse analysis, inspired in the works of Bakhtin and the Circle, are the theoretical-methodological basis of the paper. We understand that every utterance in law proceedings belongs to a genre defined in the ideological sphere of law and, as such, presents a thematic content, style, and compositional form appropriate to the genre. In addition, they constitute themselves as the unique discursive
\end{abstract}

* Pesquisadora em pós-doutorado no Programa de Estudos Pós-Graduados em Linguística Aplicada e Estudos da Linguagem /LAEL-Pontifícia Universidade Católica de São Paulo, São Paulo, São Paulo, Brasil. mhcpist@usp.br 
project of the enunciator, who occasionally combines words and images in the construction of persuasive sense. In the statements presented, the set of words and images expressed evaluative standpoints, whether in agreement or not. Moreover, the analysis showed some different voices of the countless speeches that circulate in our society.

Keywords: Law discourse. Dialogic discourse analysis. Persuasion. Verbalvisuality.

\section{INTRODUÇÃO}

Inicialmente é importante ressaltar que a verbo-visualidade tem invadido de modo crescente a esfera ideológica do Direito ${ }^{1}$, especialmente devido a aspectos da transformação das comunicações relativos à implementação do processo judicial eletrônico ${ }^{2}$ nos diferentes tribunais (permitindo a anexação de imagens de forma mais simples e rápida). Ao lado disso, tem ocorrido a abertura de páginas de diversos tribunais nas redes sociais, o que propicia mais celeridade na interação com os jurisdicionados de forma geral e ampliação do acesso a novas informaçôes judiciais ${ }^{3}$.

Tratamos aqui, porém, apenas do discurso jurídico-processual. Qual o papel persuasivo da(s) imagem(s) nesse tipo de discurso? No processo jurídico, especialmente nas áreas penal e trabalhista sobre as quais nos detivemos, imagens são razoavelmente comuns, mais especialmente - mas não apenas - nos laudos periciais. Duas questôes: serviriam elas apenas a um "iconismo probatório" ${ }^{4}$, comprovando figurativamente a alegação das partes? Teriam um valor persuasivo em si mesmas, ultrapassando a mera comprovação? Perguntaríamos ainda: poderíamos considerá-las separadamente do todo textual, como um anexo sobre o qual o

1 A realização da presente pesquisa contou com o apoio do CNPq, Conselho Nacional de Desenvolvimento Científico e Tecnológico - Brasil (Proc. 150095/2014-7).

2 O Processo Judicial eletrônico (PJe) é um sistema desenvolvido pelo CNJ em parceria com os tribunais e a participação da Ordem dos Advogados do Brasil (OAB) para a automação do Judiciário.

3 Exemplo de página do STJ: <https://www.facebook.com/stjnoticias; informação sobre falso testemunho [Citado em 20 fev.2015]: https://www.facebook.com/stjnoticias/photos/ a.10150492943061852.368576.122690696851/10151084307666852/?type=3\&theat er>.

4 Segundo Bittar (2001, p. 274-275), a presença da imagem visaria tão-somente a um "iconismo probatório", visando à "suplantação dos efeitos negativos da tradução dos fatos em linguagem verbal escrita”. 
juiz se debruça para a tomada de decisóes? $\mathrm{Na}$ realidade, não é esta a perspectiva deste trabalho: consideramos aqui cada um dos textos dos diferentes gêneros que compóem o processo judicial, inclusive o laudo pericial e os textos resultantes do processo investigativo anterior ao processo, como fruto do projeto discursivo único de um enunciador, que assume posicionamento valorativo determinado ante uma situação de direito: o sentido, pois, se constitui na relação verbal e visual, dentro da esfera ideológica jurídica.

$\mathrm{Na}$ realidade, este trabalho é fruto de pesquisa mais ampla que visa ao estudo das relações entre linguagem, argumentação e verbo-visualidade. Certo é que trabalhos relevantes com foco na verbo-visualidade têm ocorrido, sobretudo, na estética (artes, arte-educação, cinema, literatura, literatura infanto-juvenil), na semiótica (Floch, 1987; Kress, 2010), e destacadamente na área de comunicação5. Ainda que, de início, esses estudos tenham observado predominantemente a imagem, como mostravam as pesquisas da retórica visual (Barthes, 1990; GRUPO $\mu$, Édeline e Klinkenberg, 1996), textos mais recentes observam a inter-relação complementar na construção dos sentidos, com destaque, entre outros, para aqueles desenvolvidos a partir da teoria dialógica do discurso ${ }^{6}$, baseada nas obras de Mikhail Bakhtin e o Círculo, filiação teórica que compartilhamos. A especificidade do presente trabalho, contudo, deve-se a dois outros aspectos: por um lado, a ênfase na compreensão da persuasividade nessa inter-relação verbo-visual, buscando o que, “em cada caso, é capaz de gerar persuasão" (Aristóteles, 2006; 1356a), segundo concepção da antiga retórica; por outro, o próprio corpus, constituído por textos de diferentes gêneros do discurso jurídico-processual.

Após breve exposição da fundamentação teórica, apresentamos os processos cujos aspectos verbo-visuais analisaremos: um da área trabalhista e outro da área penal. A seguir, como se trata de pesquisa que temos desenvolvido ao longo deste último ano, colocaremos em diálogo os resultados da presente análise com aqueles já produzidos em ocasião anterior ${ }^{7}$, não só recuperando aspectos relevantes e comuns a todas elas, mas também observando o modo como se complementam e dando-lhes continuidade. Dessa forma, chegaremos a nossas consideraçóes finais.

5 Conforme consulta a CV Lattes, a partir dos termos verbo-visual e discurso.

6 Exemplos: Brait (2006, 2009, 2013a, 2013b, 2014); Brait B e Pistori, MHC (2012); Brait B e Dugnani BL. (2014); Grillo (2010); Pistori (2012, 2013, 2014a, 2014b, 2014c).

7 Artigo originado em comunicação apresentada no XI Congresso da Associação Internacional de Lusitanistas, Cabo Verde, 2014, aprovado para publicação em livro a ser lançado em breve: Pistori, 2014b. [Citado em 10 mar. 2015]. 


\section{O SIGNO IDEOLÓGICO, A ESFERA DE ATIVIDADE JURÍDICA E A SOCIEDADE}

A vida social viva e a evoluçáo histórica criam, nos limites de uma língua nacional abstratamente única, uma pluralidade de mundos concretos, de perspectivas literárias, ideológicas e sociais, fechadas; os elementos abstratos da língua, idênticos entre si, carregam-se de diferentes conteúdos semânticos e axiológicos, ressoando de diversas maneiras no interior destas diferentes perspectivas.

A própria língua literária oral e escrita [...] é estratificada e plurilingue no seu aspecto concreto, objetivamente semântico e expressivo.

Esta estratificação é determinada, antes de tudo, pelos organismos específicos dos gêneros. Estes ou aqueles elementos da língua (lexicológicos, semânticos, sintáticos, etc.) estáo estreitamente unidos com a orientação intencional e com o sistema geral de acentuação destes ou daqueles gêneros: oratórios, publicitários, gêneros de imprensa, gêneros jornalísticos... (Bakhtin, 1993, p. 96; grifos nossos).

Importantes aspectos do pensamento bakhtiniano, especialmente para este trabalho, se concentram no trecho recortado, extraído do ensaio "O discurso no romance", escrito por Bakhtin entre 1934-1935. O autor está refletindo a respeito do romance, da literatura, mas as consideraçôes são pertinentes à compreensão do discurso em geral, e do discurso jurídico em particular. Em primeiro lugar, destacamos a questáo de que a língua congrega uma "pluralidade de mundos [...], de perspectivas sociais e ideológicas", todos carregados de cargas semânticas e axiológicas. Com certeza, um desses mundos é constituído pela esfera de atividade jurídica, que engloba (i) o discurso legislativo (o discurso da norma); (ii) o discurso da Ciência do Direito; (iii) o discurso burocrático; (iv) o discurso jurídico-processual - dedicado à individualização e concretização do discurso normativo, foco deste trabalho (cf. Bittar, 2001, p. 176-177). Como um todo, as perspectivas sociais e ideológicas do campo do Direito são responsáveis por uma visão de mundo particular que, embora de acesso e compreensão mais restritos a especialistas, responde a valores sociais.

O plurilinguismo, que se expressa concretamente nos diferentes discursos com os quais convivemos, relaciona-se aos gêneros, que acentuam e reacentuam expressivamente os elementos da língua, determinando valores - em conflito ou 
não, que incessante e continuamente dialogam. Neste trabalho, ao tratarmos do discurso jurídico-processual, estamos lidando com os gêneros petição inicial, contestação, denúncia, laudo pericial, sentença, recursos de diferentes tipos, constituindo-se todos eles tipos de enunciados relativamente estáveis em relação a "estruturação e conclusão de um todo", à forma com que o locutor se enuncia e se dirige ao objeto e ao destinatário - o estilo, e à temática de que tratam, numa interação essencial e axiologicamente tensa entre o que é interior e exterior aos enunciados (Bakhtin, 2006, p. 261-262; 1993, p. 69). Assim, como atos social e historicamente determinados, cada enunciado concreto não se compreende táo-somente em si mesmo, pois se orienta também para o extraverbal, para o contexto em que se insere (Medviédev, 2012, p. 195-6).

O trecho recortado trata ainda dos elementos da língua - "lexicológicos, semânticos, sintáticos, etc.", intimamente relacionados à questão dos gêneros. E, em relação à palavra, é oportuno ressaltar alguns aspectos fundamentais para o pensamento bakhtiniano: em primeiro lugar, a questão de que nela ressoa o gênero em sua totalidade (Bakhtin, 2006, p. 312); em segundo, o fato de que ela é o "fenômeno ideológico por excelência" (Bakhtin/Volochínov, 1981, p. 36); e, enfim, a afirmação de que sua realidade é a função de signo e, mais precisamente, signo ideológico (Bakhtin/Volochínov, 1981, p. 44-47). Nela, pois, se confrontam indices de valor contraditório, uma orientação e entonação apreciativas próprias da esfera ideológica em que está inserida. Importante também destacar que, para o Círculo, a abordagem da palavra e do discurso sempre se dá a partir do uso, do enunciado concreto; e discurso compreendido como algo que ultrapassa o puramente linguístico (cf. Bakhtin, 2008, p. 207-211) .

Conhecido trecho da obra bakhitiniana afirma que o enunciado é um elo na cadeia criativa de enunciados, todos dialogando entre si, ora respondendo, refutando, confirmando, antecipando objeçóes potenciais, procurando apoio etc., com enunciados anteriores ou futuros. Este o sentido de dialogia para o Círculo, diálogo num sentido amplo, constituído pela interação verbal, fenômeno social que constitui o locutor e o interlocutor, sujeitos da enunciação (Bakhtin/ Volochínov, 1981, p. 123). Os autores esclarecem também que as relaçôes dialógicas ocorrem entre posiçôes semânticas, os posicionamentos; podem, então, acontecer entre

8 A concepçáo bakhtiniana de discurso está exposta com muita clareza no capítulo "O discurso em Dostoiévski", de Problemas da poética de Dostoiévski: "a língua em sua integridade concreta e viva e não a língua como objeto específico da linguística, obtido por meio de uma abstração absolutamente legítima e necessária de alguns aspectos da vida concreta do discurso" (Bakhtin, 2008, p. 207). 
enunciados, ou entre palavras - mesmo uma palavra isolada, "se nela ouvimos a voz do outro", ou entre elementos expressos em qualquer "matéria sígnica", o que certamente inclui a imagem (Bakhtin, 2008, p. 210-211). É isso que torna o discurso bivocal, conforme observaremos nas análises. E, como tratamos aqui da verbo-visualidade na esfera ideológica do Direito, importante dizer que, para o Círculo, a ideologia se expressa não apenas no material verbal, pois é "todo o conjunto de reflexos e refraçóes no cérebro humano da realidade social e natural, expressa e fixada por ele sob forma verbal, de desenho, de esboço ou de outra forma semiótica" (Volochínov, 2010, p. 533, grifos nossos) ${ }^{9}$. Assim, ainda que cada uma das esferas tenha seu próprio modo de encarar (refletir e refratar) a realidade, o sentido dos enunciados concretos ocorre a partir do diálogo entre elas e da compreensão responsiva e ativa entre os parceiros da comunicação discursiva, "uma resposta a um signo por meio de signos" (Bakhtin/Volochínov, 1981, p. 34). Expostos os conceitos bakhtinianos fundamentais que baseiam este trabalho, partimos para a análise.

\section{UM PROCESSO TRABALHISTA}

Os gêneros do discurso jurídico são bastante padronizados, enquadram-se entre aqueles sobre os quais Bakhtin (2006, p. 283) afirma não serem os mais aptos ao estilo individual ${ }^{10}$; mas, como qualquer gênero, apresentam uma entonação expressiva e uma temática própria. Assim, no discurso do Reclamante - aquele que propóe a ação na área trabalhista -, o tema é a busca de direitos devidos e não cumpridos pela empresa; no discurso da Reclamada encontra-se a contestação das alegaçóes do autor; e, na decisão, a resolução do conflito, que responde às partes. O diálogo ocorre entre os discursos, mas também com a própria sociedade, com o contexto jurídico, a legislação, a doutrina, a jurisprudência, e ainda com os valores sociais, mas não coincidentes entre as partes, como veremos. Não trataremos de todos os textos, apenas de aspectos relacionados à verbo-visualidade naqueles que utilizam a imagem - a petição inicial e o laudo pericial; e, depois, observaremos como a decisão dialogou com eles.

9 Texto original: "Par idéologie, nous comprenons tout l'ensemble de reflets et de réfractions dans le cerveau humain de la réalité sociale et naturelle, exprime et fixé par lui sous forme verbale, de dessin, croquis ou toute autre forme sémiotique”. Sobre o conceito, cf. ainda Faraco (2009, p. 45-50) e Grillo (2008, p. 133-160).

10 Ainda assim, uma análise acurada determina individualidades próprias nos enunciados de diferentes enunciadores (Cf. Pistori, 2008). 


\subsection{A petição inicial}

O processo selecionado, proc. $\mathrm{N}^{\circ} .0000023-90 ; 2013.5 .15 .0116$, não foge à regra. Vamos apresentá-lo de forma breve, detendo-nos no que nos interessa: a persuasividade verbo-visual. Na petição inicial, a autora, A. J. T., por meio de seus advogados, após identificação e apresentação de dados de seu contrato de trabalho (I), trata da doença ocupacional (II) "em decorrência do trabalho" que exercia na empresa $\mathrm{X}$, fabricante de materiais elétricos e produtos correlatos para fins automotivos. Tendo lá trabalhado ao longo de nove anos, de 2003 a 2012, em 2004 surgiu-lhe um "cisto sinovial no dorso do punho direito", causando-lhe "fortes dores". Submetida a dois procedimentos cirúrgicos para retirada do nódulo, isso "resultou numa cicatriz hipertrófica na mão direita" (fl.4). Segundo a petição, como a empresa contrariou determinação médica de "restrição de horas extras", em 2009 a moça "foi surpreendida com o reaparecimento do cisto sinovial em seu punho direito, bem como passou a sofrer de sérios problemas psíquicos (depressão), fibromialgia, além das dores residuais” (fl.4). Finalizando a parte narrativa, a petição solicita ao juízo trabalhista "designação de perícia médica, para que seja avaliado o grau da redução ou perda de capacidade ocupacional da autora” (fl.5).

A seguir (III), apresenta ampla argumentação a respeito do alegado "nexo de causalidade e da responsabilidade do empregador", inserindo Normas Regulamentadoras do Trabalho, aspectos do Programa de Prevenção de Riscos Ambientais, do Programa de Controle Médico de Saúde Ocupacional, tabela parcial de Mapa de Riscos de Acidentes do Trabalho, para concluir que "a empresa no mínimo se omitiu na aplicação das normas de segurança e medicina no trabalho, ou senão, negligenciou-se deixando seus funcionários à própria sorte no momento em que não se antecipou, reconheceu, avaliou e controlou os riscos..." (fl.7; grifos no original). A crescente gradação expressiva dessas açôes que, segundo o enunciador, caracterizam o "ato ilícito previamente avaliado e consentido, portanto criminoso" da empresa, ao lado de toda avaliação referente ao sucedido com a trabalhadora - "lesão à integridade psicofísica, decorrente de acidente de trabalho, por si só, [é] capaz de causar danos, sejam material ou moral"; "... o dano moral [...] traz repercussốes negativas, aptas a causar abalos psíquicos de dor, sofrimento e angústia"; "as atividades exercidas pela reclamante em benefício da empresa ocasionaram o acidente/moléstia, incapacitando-a para o trabalho habitual, o que lhe causou, por óbvio, diminuição de sua autoestima..." (fl.8) -, ressaltam e enfatizam retoricamente o posicionamento do enunciador. Além disso, o enunciado afirma que os "documentos atrelados à inicial" (entre os quais as três páginas com fotos, das fls. 46 a 48), que destacam o nódulo no punho da trabalhadora, servem de justificativa ao pedido que encerra este item: 
que a empresa pague à trabalhadora indenização por "danos morais". Não vamos nos deter nos itens seguintes da petição - solicitação de danos materiais, plano de saúde, etc. Tratemos das fotografias.

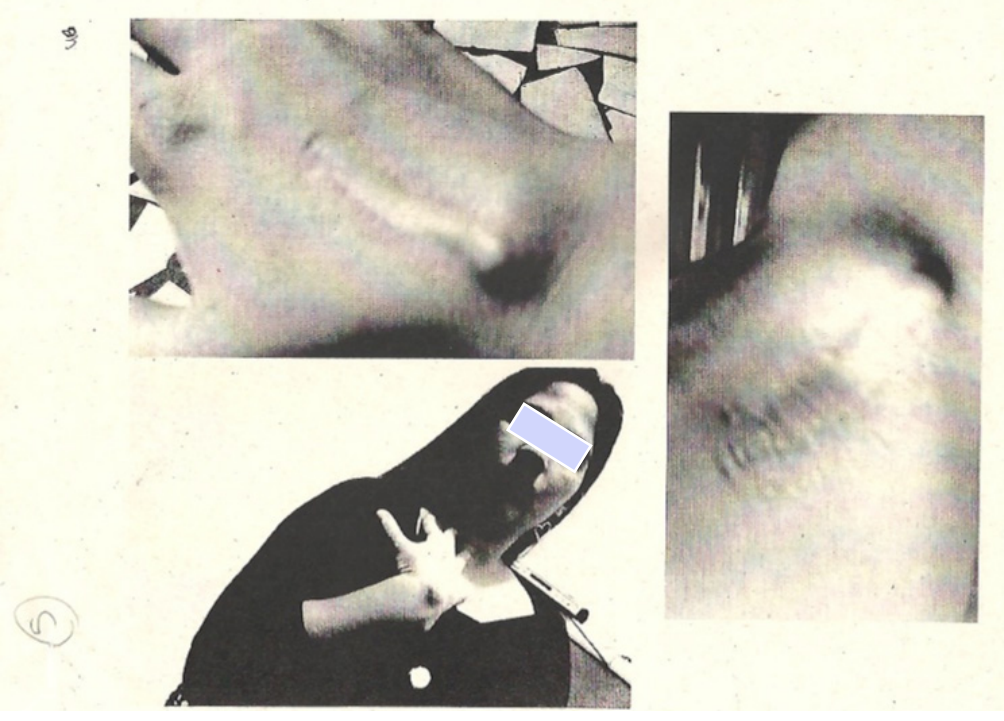

Figura 1 - Petição inicial

Barthes (1990), ao analisar a mensagem fotográfica, já alertava que seu aspecto "denotante" se arriscava a ser mítico, lembrando que "o significado, quer estético, quer ideológico, remete a uma certa cultura da sociedade que recebe a mensagem" ${ }^{11}$. Em nossa chave teórica, nós a consideramos um signo ideológico, tal qual a palavra, cujos sentidos se constroem na conjugação entre texto e imagem - as palavras da petição inicial e os documentos atrelados a ela, entre eles, as fotos. E, neste caso, observamos que as fotografias (Figura 1) são fortemente persuasivas, não se restringindo à expressão objetificada do referente. Por meio do ângulo a partir do qual foram tiradas e ainda do jogo de luz e sombra nas imagens, elas destacam mais do que uma "cicatriz hipertrófica", mas o que parece ao destinatário o próprio nódulo proeminente e rombudo, de volume considerável e cortado longitudinalmente de pequenas estrias superficiais, remanescente das intervenções cirúrgicas. Na realidade, tal como afirma Bakhtin a respeito da narração de um

11 Texto original: “... le signifié, soit esthétique, soit idéologique, renvoit à une certaine “culture" de la societé qui reçoit le message" (Barthes, 1961, p.128). 
romance, na narrativa dos fatos dessa petição inicial as fotos são utilizadas para servir aos propósitos do enunciador, ao expor um ponto de vista que conduz sua narração (Bakhtin, 2008, p. 218). Como um discurso bivocal, elas orientam-se para o mesmo fim do discurso do enunciador/autor, com ele concordando. Por isso, é importante que, ao estudá-las, não as separemos do "enquadramento contextual (dialógico): um se relaciona indissoluvelmente ao outro" (Bakhtin, 1993, p. 141).

Assim, ainda que de início pudéssemos considerá-las um discurso referencial direto e imediato orientado para seu referente, se pensarmos no esquema dinâmico com o qual Bakhtin busca mostrar as relações dialógicas entre discursos, poderíamos afirmar que elas constituem o discurso da pessoa representada (do "herói"): um "ponto de vista especifico sobre o mundo e sobre si mesma"(Bakhtin, 2008, p. 52), isto é, discurso do outro, mas objeto da intenção do autor (Bakhtin, 2008, p. 188). As consciências - do autor e da personagem - coincidem, "estâo lado a lado diante de um valor comum", configurando o acontecimento ético, tal como "o panfleto, o manifesto, o discurso acusatório, o discurso laudatório e de agradecimento, o insulto, a confissão-relatório" citados por Bakhtin (2006a, p. 20). E, neste caso, não podemos deixar de notar que a perspectiva acentua o caráter patético das imagens, que apelam à compaixão do destinatário, seguindo antiga lição da Retórica de Aristóteles (2006; II, 1377b, 20): "nos processos, importam principalmente as boas disposiçôes dos ouvintes, porque os fatos não se revelam através do mesmo prisma, consoante se ama ou se odeia, se está irado ou em inteira calma”. Isto é, elas são "as causas que introduzem mudanças em nossos juízos" (Aristóteles, 2006; II, 1377b, 28) e acrescentam "uma dramaticidade interior ao enunciado" (Bakhtin, 2006, p. 302). Apenas para finalizar, eis o que o Estagirita afirma sobre a compaixão:

Admitamos ser a compaixão uma espécie de pena causada por um mal aparente capaz de nos aniquilar ou afligir, que fere o homem que não merece ser ferido por ele, quando presumimos que também nós podemos sofrer, ou algum dos nossos, e principalmente quando nos ameaça de perto. Evidentemente é mister que o homem que haja de sentir compaixão pense que ele próprio, ou algum dos seus, é suscetível de sofrer de um mal idêntico ao que indicamos em nossa definiçáo, ou de mal análogo, ou parecido (Aristóteles, 2006; p. 13; II, 1385b, 13). 


\subsection{O laudo pericial}

Conforme solicitação das partes, o magistrado requisitou que uma perícia médica investigasse e avaliasse "eventual nexo de causalidade da moléstia com as funções exercidas/local de trabalho, declinando o grau de incapacidade do autor para o trabalho, se houver, descrevendo, de modo minudente, o ambiente de trabalho, as funções exercidas, sua intensidade e repetição" (fl.53). A empresa contestou todos os pedidos da Reclamante, negando nexo causal entre a doença e a ocupação da autora, rejeitando todos os demais pedidos: indenização por dano moral, dano material, plano de saúde e outros, e apresentando ainda laudo pericial elaborado por perito da própria empresa. O laudo do Instituto de Medicina do Trabalho (IMT), cujos serviços de perícia foram designados pelo juiz, é o próximo enunciado que observaremos mais de perto. Trata-se de um longo documento, que se inicia à fl. 358 e termina à fl. 387 , e busca responder a quesitos elaborados pelas partes. Contextualiza o trabalho realizado, com um histórico resumido dos fatos e pedidos para, então, apresentar a "Perícia física/ Histórico clínico laboral e a Vistoria técnica na reclamada - análise das condiçóes ergonômicas de trabalho". Náo vamos nos deter em seus detalhes, pois nos importam as onze fotos (Figura 2) com legenda e o modo como dialogam com o texto, especialmente a conclusão a que chegou o médico. Antes delas, assim descreve o perito o "exame físico especial" efetuado: "MÃO DIREITA - cicatriz cirúrgica, na região dorsal do punho, entre o $2^{\circ}$. e $3^{\circ}$ metacarpo de $3,5 \mathrm{~cm}$ de comprimento, passando a prega do punho, devido cisto sinovial" (fl.362). A seguir, nas fotos, mal vemos essa cicatriz, tão destacada nas fotos da petição inicial. Elas mostram, predominantemente, a possiblidade e extensão dos movimentos permitidos pelas mãos da Reclamante: movimentos para cima, para baixo, para os lados, para trás, com mãos juntas e separadas, paralelas, em frente ao rosto etc. Nessas fotos podemos perceber que todos os movimentos manuais parecem ser possíveis para a Reclamante, ainda que nem sempre os braços e mãos se posicionem simetricamente. 

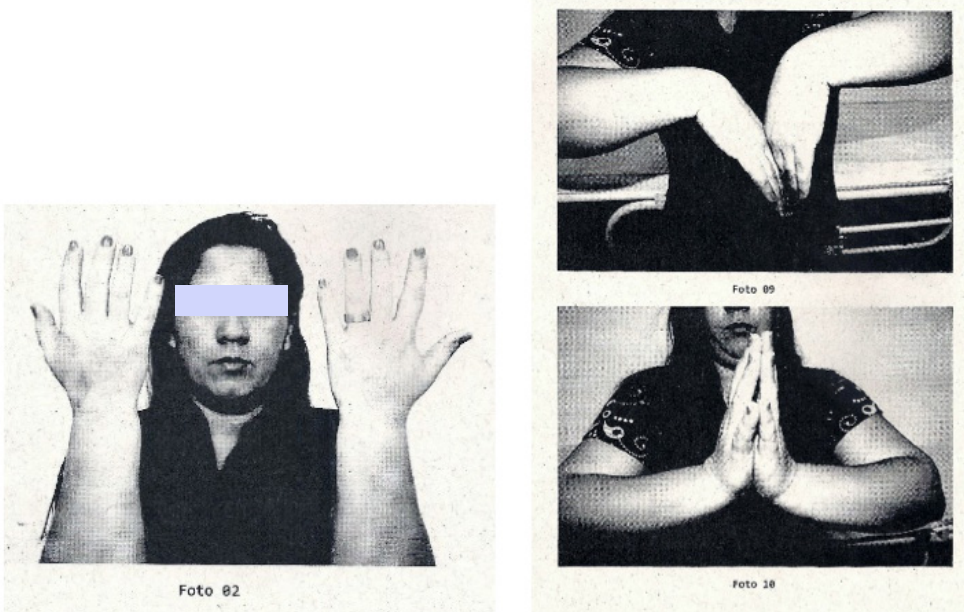

Figura 2 - No laudo pericial

Das conclusóes, extraímos apenas o que tange a nossos objetivos:

1 - conforme pudemos constar, as tarefas realizadas na reclamada, são ALTAMENTE REPETITIVAS com as extremidades dos membros superiores, máos/punhos; [...] 5 - CONCLUÍMOS QUE: a reclamante sofreu TENOSSINOVITE NO PUNHO DIREITO e o CISTO SINOVIAL, embora não seja uma doença profissional e possa ocorrer na população em geral por fragilidade da capa dos tendóes, neste caso foi precipitado ou agravado pelas condiçôes de trabalho (fl.378).

Mais adiante, após a inserção de trechos ilustrados de literatura médica a respeito das etiologias dos cistos sinoviais, o laudo apresenta a conclusão da perícia, do qual destacamos a afirmação de que a Reclamante "trabalhou em condições ergonômicas de riscos" para a moléstia; "sofreu tenossinovite no punho direito devido condições de trabalho [...] a doença psiquiátrica DEPRESSÃO não tem relaçóes com o trabalho, mas podem agravar suas condiçôes físicas articulares". Finalmente, afirma que, "quanto à incapacidade laborativa, está contra indicada para trabalhar na função original” (fl.381). Conforme podemos constatar, as fotos também se constituem um discurso referencial direto, expressão objetificada do referente; ainda que discurso de outrem, servem à intenção do autor mas, diferentemente das fotos da petição inicial, nelas não percebemos a dramaticidade, o apelo ao pathos do destinatário. Elas estão bem mais próximas do que Bakhtin 
(2008, p. 228) chamou de "discurso direto imediatamente orientado para o seu referente como expressão da última instância semântica do falante".

\subsection{A sentença}

$\mathrm{Na}$ sentença o juiz não concede a indenização de dano material à autora e também não faz qualquer referência às fotos, concluindo que, apesar do nexo de causalidade entre a ocupação exercida na empresa e a doença, ela sofreu apenas uma "incapacidade parcial e temporária que reduziu potencialmente sua mobilidade no mercado de trabalho": "A opinião do senhor perito, a partir do exame clínico que realizou em 16.09.2013, indica que a autora já não estava incapacitada para o trabalho, sem qualquer processo inflamatório no pulso, embora ainda possua uma cicatriz decorrente da cirurgia que realizou (fl.398; grifos nossos)". Concedeu-lhe, entretanto, a indenização por dano moral, justificando:

As intervenções cirúrgicas a que se submeteu lhe causaram uma marca estética nas proximidades da mão direita. Mesmo quando se pondera a consolidação da lesão funcional, há que se ponderar que a temporária imobilidade causada no membro superior impacta a autoestima da autora que se vê na contingência de náo conseguir realizar tarefas mínimas, mormente em sua residência. Assim, há três dimensôes de ofensa a personalidade humana na conduta da reclamada: a ofensa à proteção previdenciária; a incapacidade temporária que impacta a autoestima e o agravo estético. Fixo o dano moral decorrente da exposição do reclamante aos riscos ambientais no trabalho criados pela reclamada em $\mathrm{R} \$$ 100.000,00 como incentivo econômico e pedagógico à revisão dos seus métodos de administração do trabalho, já que o que se verifica é a prática de atos conducentes à violação de direitos fundamentais da autora, para além da própria atividade econômica e os riscos ambientais a ela associados (fl.399-400; grifos nossos).

Isto é, o discurso do perito foi ouvido - a autora pode continuar a trabalhar, desde que em outra função; mas também foi ouvido o apelo da Petição inicial: embora não mencionada ali a questão estética da "cicatriz hipertrófica", as fotos falaram mais alto, persuasivamente. E o dano moral foi concedido extensivamente, 
considerando também o "agravo estético" à trabalhadora, na medida em que "impacta a autoestima".

\section{UM PROCESSO PENAL}

No processo penal que selecionamos as fotografias exercem uma função diferente, mas igualmente interessante no sentido de observarmos as possibilidades persuasivas da verbo-visualidade na esfera de atividade jurídica. Conforme dados da Denúncia, o delito - homicídio tentado por motivo torpe - ocorreu em agosto de 2012. É o caso de um rapaz, Anderson L. P. S., que, acompanhado de um menor de idade, aborda um guarda municipal na garagem de sua casa e "subtrai, para si, mediante violência e grave ameaça exercida com emprego de arma de fogo, uma motocicleta da marca Honda, modelo CBX 250 Twister, placa MBO-2065, uma carteira contendo $\mathrm{R} \$ 40,00$ (quarenta reais) em dinheiro e um aparelho de telefonia celular" (fl.01). Ao verificar a carteira da vítima, porém, o adolescente descobre que é um guarda municipal e grita para o outro: "Mata, mata que ele é Polícia". Há troca de tiros e o adolescente, ferido, é preso, para "responder a ação sócio educativa junto à Vara da Infância e da Juventude”, mas o outro agressor foge. Quase um ano mais tarde, o autor do delito é identificado, reconhecido pela vítima e preso. Instaurou-se inquérito policial e, por meio do Boletim de Ocorrência, ficamos sabendo que, no momento em que o autor do delito "evadiu-se levando o celular da vítima [...] foi localizado no local um celular que pertencia a um dos meliantes e que continha fotos de ambos exibindo armas de fogo" (fl.06). Essas fotos foram copiadas pela vítima e, posteriormente, distribuídas aos guardas municipais. Foi dessa forma que se conseguiu a identificação do agressor, reconhecido pela vítima na Distrital, "como um dos autores do roubo". O processo correu em ritmo próprio, tendo o réu sido condenado ao final, conforme solicitado pela Denúncia, em Tribunal do Júri, que julga as açôes lesivas à vida. Duas questôes nos chamam atenção, porém, levando em consideração o foco deste trabalho.

Em primeiro lugar, as próprias imagens encontradas no celular dos "roubadores". Como vimos, elas serviram à identificação do autor do homicídio tentado: são quatro fotos em preto e branco - duas de cada um, reveladas no tamanho 10 x 15, e encontram-se nas fls. 113 a 116 do processo. Destacam-se por sua expressividade: apesar de muito escuras, veem-se nelas, em imagens separadas, cada um dos rapazes - poderíamos dizer, se pavoneando, ostentando a arma nas mãos, em posição pronta para atirar. $\mathrm{Na}$ realidade, parecem mesmo fotos de 
bandidos (Figura 3): cenário próprio - sem qualquer glamour, bebidas e fumo (?), a figurativização da esfera ideológica do crime. Na primeira delas, o réu - branco, está de pé, ligeiramente postado de lado, mas olhando para a câmera, cabelos curtos muito bem penteados para trás (com gel), óculos escuros de aros claros e pequenos, elipticamente arredondados, pequeno brinco na orelha esquerda, segurando um cigarro; no braço ostenta um relógio e, na mão direita, um revólver que parece pronto para atirar. As roupas são escuras e contrastam com o ambiente, em cujo fundo reconhecemos uma geladeira; o teto parece inconcluso, isto é, uma laje sob a qual se veem fios meio soltos. Na segunda foto, a postura do moço é frontal. $\mathrm{Na}$ boca, parece ter alguma coisa, pois a bochecha direita está inflada; já o modo como segura o cigarro sugere ser de maconha. Nesta pose, o revólver está apontado obliquamente para frente, para a direita. As roupas escuras são as mesmas, mas o ambiente de fundo agora retrata uma sapateira de plástico, fechada com zíper, e várias sacolas cheias, de diferentes tipos, estão penduradas no teto e na parede. Além disso, o próprio fato de ambos se fotografarem nessa postura é chocante: dialoga com um mundo em que regras e valores sociais não prevalecem nem parecem ter qualquer importância, é o horizonte social da barbárie, em meio à civilização de Direito em que vivemos.
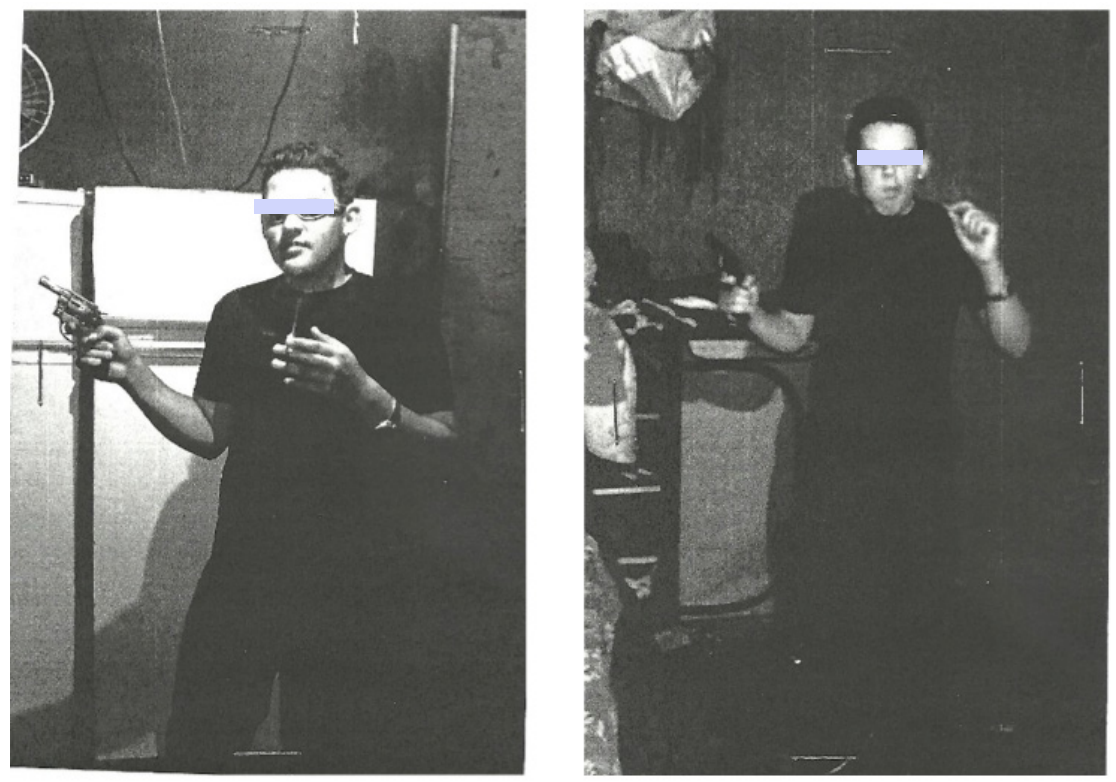

Figura 3 - Na investigação policial 
Em segundo lugar, notamos que o sentido das fotos náo se encerra nelas mesmas. No processo, elas não apenas deram ensejo ao reconhecimento do réu, mas exerceram um papel maior na convicção do juiz, que acatou a classificação do delito tal qual alegada pelo Ministério Público na Sentença de Pronúncia ${ }^{12}$ : homicídio tentado por motivo torpe, ainda que a Defesa tenha afirmado que "o réu deve ser impronunciado, pois a única prova a incriminá-lo é a palavra da vítima, prova essa frágil e insuficiente" (fl. 99). Certo é que em vários pontos do processo encontramos o alerta do magistrado de que

no processo penal democrático, que deve desenvolver-se sob os auspícios do contraditório e da ampla defesa, os elementos colhidos durante a fase investigatória [...] não têm valor probante para embasar um decreto condenatório nem para fundamentar uma decisão de pronúncia, pois esgotam sua eficácia probatória com a admissão da acusação, mas, inquestionavelmente, servem para motivar e fundamentar medidas cautelares e outras restriçóes adotadas no curso da fase pré-processual, bem como para justificar o processo ou o não processo (fl.58-9; grifos nossos).

Tal justificativa se repete algumas vezes em novas decisôes interlocutórias anteriores à final, com a advertência, porém, de que tais elementos "são hábeis para demonstrar a probabilidade do fumus comissi delicti para justificar o processo (recebimento da ação penal) ou o não-processo (arquivamento)" (fl. 80-81). Adiante, encontramos mais uma decisão interlocutória cujas solicitações são, entre outras, justamente a "juntada de documentos a este juízo pela vítima L. C. S. F., a saber: quatro fotografias [...] para inquirir a vítima a respeito desses documentos". A importância das fotos e do celular apreendido pela vítima se destaca ainda na sequência:

3. Verifique a serventia se o Depósito de Armas e Objetos recebeu o CELULAR apreendido (v. Als. 09).

4. Caso o referido celular não tenha sido encaminhado ao depósito, oficie-se ao $3^{\circ}$. DP, ao $1^{\circ}$. DP e à Delegacia da Infância e Juventude, solicitando-se informaçóes e o

12 A sentença de pronúncia é uma decisão que não póe fim ao processo: ela apenas decide que existem indícios de um crime doloso contra a vida, que o acusado pode ser o culpado e que, por se tratar de um crime doloso contra a vida, o processo será julgado por um tribunal do júri e não por um juiz sozinho. 
encaminhamento imediato de tal celular a este juízo no prazo de cinco dias. (fl.109).

Concluindo, as fotos não serviram ao julgamento pelo Tribunal do Júri, mas à convicção do magistrado no momento em que aceitou a Denúncia nos termos em que foi feita. E destacamos que nela não houve qualquer menção às imagens, que surgem e ampliam sua importância no processo a partir da fase investigatória. Como vemos, textos e imagens devem ser compreendidos em conjunto.

\section{CONSIDERAÇÓES FINAIS. O DIÁLOGO ENTRE AS ANÁLISES}

Com o intuito de dar acabamento mais amplo (ainda que sempre provisório) a este texto e, sobretudo, à pesquisa de que faz parte, vamos nos permitir, neste item, recuperar achados de observaçóes e análises anteriores para dialogar com as análises aqui efetuadas. Primeiramente, tratando do processo trabalhista, é importante ressaltar que as imagens nos laudos periciais, tais como as apontadas neste processo, são a ocorrência mais comum. Na realidade, como expressão objetificada do referente, servem realmente a um "iconismo probatório", fundamentando e justificando as conclusóes do perito. Da mesma forma, esse tipo de discurso direto "imagético" acontece comumente também no processo penal: são fotografias da vítima, da cena do crime etc. Naturalmente, em cada caso cabe uma análise mais profunda do ponto de vista do enunciador e dos diferentes ângulos utilizados, contudo poderíamos afirmar que servem predominantemente como a objetificação do referente, suplantando os "efeitos negativos da tradução dos fatos em linguagem verbal escrita”, segundo as palavras de Bittar (2001, p. 274-275). Trata-se de persuasão, mas diríamos que, preferentemente, baseada no logos, o discurso, pelo que ele demonstra ou parece demonstrar, segundo Aristóteles.

O caso trabalhista que destacamos, contudo, foi um pouco diferente e nisso reside, a nosso ver, seu interesse do ponto de vista do estudo da persuasão no processo judicial constituído verbo-visualmente. Pudemos aí observar que as imagens, assim como as palavras, claramente se apresentam num discurso bivocal complementar que concorda e dá apoio ao projeto discursivo do enunciador. Mas, na justificativa com que o juiz concede parte dos pedidos à trabalhadora, percebemos que sua compreensão responsiva dos fatos discursivos se estendeu para além do dano moral, considerando o agravo estético, que não havia sido pedido. A justificativa do magistrado coloca ativamente em diálogo os discursos da Reclamante e o próprio discurso legal, ambos orientados na mesma direção, 
defendendo os mesmos valores sociais de respeito aos direitos trabalhistas, mas o discurso da norma tem amplitude maior.

Já no processo que analisamos em outro trabalho (Pistori, 2014b), também relativo a danos morais, materiais e estéticos sofridos por um empregado em acidente de trabalho na empresa, as fotos inseridas na petição inicial ensejaram outra leitura do destinatário final, a turma de julgadores da segunda instância. Nesse caso, verificamos que palavras e imagens - signos ideológicos marcados pelo horizonte social de uma época - remetem a índices de valor que não estão estabilizados, valores que são dinâmicos. Explico: da mesma forma que no processo trabalhista aqui analisado, naquele constavam imagens dos danos sofridos pelo trabalhador nos membros inferiores (Pistori, 2014b). Conforme relatório que acompanha a decisão colegiada de segunda instância, foram concedidas ao empregado as reparaçóes por danos morais e materiais, mas não a solicitação de indenização por danos estéticos, com a justificativa seguinte: "por ser do sexo masculino e de pele morena, as cicatrizes não ficam tão em evidência”. Assim, o discurso bivocal, nesse caso, ainda que voltado para o referente, com ele abertamente polemizou na compreensão responsiva e ativa do destinatário. E isso nos levou a comentar criticamente, naquela análise, que, "em plena vigência constitucional de um discurso que reconhece direitos iguais para todos, deparamo-nos com uma justificativa, num processo legal, sexista e racista... Mas sua compreensão remete ao exterior do texto, exterior compreendido e depreendido do texto" (Pistori, 2014b).

Especialmente em relação aos processos da área penal, pudemos observar uma variedade de usos persuasivos da verbo-visualidade. No processo que analisamos aqui, o foco é o confronto discursivo que se configura nas imagens, em que valores próprios ao mundo do crime se opõem àqueles da sociedade democrática de Direito. A explicitação discursivo-figurativa desses valores nas fotos do acusado contribuiu à constituição do convencimento do magistrado, que acatou a denúncia e proferiu a Sentença de Pronúncia, levando o acusado a ser julgado pelo Tribunal do Júri.

No processo analisado anteriormente, também as relaçôes dialógicas entre palavras e imagens evidenciaram o reconhecimento dos posicionamentos axiológicos em jogo (Pistori, 2014b). As fotos inseridas em enunciados de uma das defesas, juntamente com a entonação apreciativa altamente positiva em relação ao caráter do réu - do que se inferiria que estava sendo injustamente julgado -, serviram à identificação dos valores sociais em confronto: (i) os valores do privilégio social expresso em inúmeras fotos, que exaltavam valores exclusivos, como educação em escola religiosa, intercâmbios, universidades públicas, estudo de inglês, academia de musculação etc., trabalho e família. No caso, também como um discurso direto 
imediatamente voltado para o referente, em concordância com o enunciador, promoviam tal detalhamento com o fito de firmar a ilusão de verdade; (ii) os valores de igualdade democrática, expresso em foto que buscava apontar polemicamente a mídia como a responsável por incitar a indignação da opinião pública, não o delito. Nesse caso, interessante foi notar o uso persuasivo da imagem como epígrafe do texto, conferindo ao enunciado como um todo o tom volitivo-emocional de indignação ante a mídia, simultaneamente ao de compaixão em relação ao réu, sua vítima; (iii) os valores de igualdade racial, colocando foto $3 \times 4$ do réu para ilustrarlhe a seriedade, afirmando não se tratar de alguém "sem profissão", e acusando a mídia de prática de discriminação em relação a ele ${ }^{13}$, o que - segundo o texto, poderia interferir negativamente em seu julgamento. Em todos os exemplos, o apelo emocional ao pathos do destinatário esteve presente e atuante.

Enfim, retomemos o objetivo deste artigo e da pesquisa em que se insere: a verificaçâo das formas como a verbo-visualidade é usada argumentativamente no discurso jurídico-processual. Partindo daí, podemos afirmar que as análises realizadas foram capazes de mostrar diferentes usos e possíveis interpretaçóes do projeto discursivo único a que se dedicou cada um dos enunciadores que aliaram os diferentes signos ideológicos - palavras e imagens. Pudemos comprovar que os sentidos se constroem na relação palavras e imagens, mas tal relação engloba ainda interior e exterior do discurso: como signos ideológicos, ambos remetem à esfera da atividade jurídica e também à própria sociedade, de modo mais amplo, e ao horizonte social de nossa época. Além disso, tanto nas palavras como nas imagens e em sua relação confrontam-se índices de valor contraditório, claramente visíveis, nem sempre estabilizados: por exemplo, na compreensão responsivo-ativa da turma de julgadores que negou reparação por dano estético ao trabalhador por ser ele negro e homem. Mais ainda: a orientação apreciativa e o tom volitivo-emocional se depreendem não apenas da palavra, mas também das imagens e da sua relação com as palavras, como vimos no caso da trabalhadora que obteve indenização por dano estético ao ter solicitado dano moral; e também no caso da fotografia que os "meliantes" fizeram de si mesmos.

Antes de concluirmos, porém, cabe um último comentário. Há uma especificidade no modo como tem se expressado, majoritariamente, a verbo-visualidade

13 Proc. 17.901/97, que julgou rapazes que assassinaram um índio pataxó em Brasília, em 1997: "A fotografia do acusado, de preferência sobre os demais co-réus, é frequentemente estampada nos periódicos locais, com alcunhas de assassino e monstro, realçadas pela sua origem negra, de tez acentuadamente morena, com ofensa aos mais elementares direitos e garantias fundamentais do cidadáo" (fl. 550). 
no discurso jurídico-processual. Trata-se, sempre, do projeto único do enunciador que assina valorativamente seu texto, mas a integração palavras e imagens - essas últimas comumente aparecem nos anexos - é bem diferente daquela que acontece no discurso jornalístico ou no publicitário, alvo de análises que realizamos anteriormente. Talvez a única exceção tenham sido os enunciados de defesa no primeiro processo penal selecionado, em que as imagens ora introduziam o texto, como uma epígrafe, ora ilustravam características físicas e morais do acusado. Isso nos permite afirmar que, na realidade, há ainda possibilidades persuasivas da verbo-visualidade a serem mais exploradas na esfera de atividade jurídica, como parece ser o caso de recentes páginas eletrônicas dos tribunais, que já se deram conta da riqueza dessa inter-relação. Enfim, conforme previsto, os resultados mostram ganhos teóricos e práticos não apenas na compreensão das relaçôes entre linguagem, argumentação e visualidade, como também em termos das relaçóes entre o próprio Direito e a sociedade.

\section{REFERÊNCIAS}

Aristóteles. Retórica. Manuel Alexandre Júnior, tradutor. $3^{a}$ ed. Lisboa: Imprensa Nacional; Casa da Moeda; 2006.

Bakhtin M. O discurso no romance. In: Bakhtin M. Questôes de literatura e de estética. A teoria do romance. Aurora Fornoni Bernadini et al., tradutores. $3^{\text {a }}$.ed. São Paulo: UNESP; 1993. p. 71-210.

Bakhtin M. Os gêneros do discurso. In: Bakhtin M. Estética da criação verbal. 4.ed. Trad. Paulo Bezerra. São Paulo: Martins Fontes; 2006. p. 261-306.

Bakhtin M. O problema do conteúdo, do material e da forma na criaçáo literária. In: Bakhtin M. Estética da criação verbal. 4.ed. Trad. Paulo Bezerra. São Paulo: Martins Fontes; 2006. p. 307-336.

Bakhtin M. O problema do texto na linguística, na filosofia e em outras ciências humanas. In: Bakhtin M. Estética da criação verbal. Trad. Paulo Bezerra, tradutor. $4^{a}$ ed. São Paulo: Martins Fontes; 2006. p. 307-336.

Bakhtin M. Problemas da poética de Dostoiévski. Paulo Bezerra, tradutor. 4a ed. Rio de Janeiro: Forense Universitária; 2008. 
Bakhtin M (Volochinov VN). Marxismo e filosofia da linguagem. Problemas fundamentais do método sociológico na ciência da linguagem. Michel Laud e Yara F. Vieira, tradutores. $8^{a}$ ed. São Paulo: HUCITEC; 1981.

Barthes R. Le message photographique. Communications. 1961;1:127-138. [citado em 20 fev. 2015]. Disponível em: http://www.persee.fr/web/revues/home/prescript/article/ comm_0588-8018_1961_num_1_1_921.

Bittar ECB. Linguagem jurídica. São Paulo: Saraiva; 2001.

Brait B. A construção do sentido: um exemplo fotográfico persuasivo. Língua e literatura. 2015; 21: 19-27.

Brait B. Revisitando mitologias pelas lentes dialógicas. Desenredo. 2014;10:9-30. [citado em 20 fev. 2015]. Disponível em: http://www.upf.br/seer/index.php/rd/article/ view/4094/2638

Brait B. Olhar e ler: verbo-visualidade em perspectiva dialógica. Bakhtiniana: Revista de Estudos do Discurso, 2013a;8:43-66. [citado em 20 fev. 2015]. Disponível em: http:// revistas.pucsp.br/index.php/bakhtiniana/article/view/14141/12911

Brait B. Jean Peytard, dialogisme et analyse du discours. Synergies Monde. 2013b; 10:1727. [citado em 20 fev. 2015]. Disponível em: http://www.persee.fr/web/revues/home/ prescript/article/igram_0222-9838_1996_num_71_1_2981_t1_0059_0000_2

Brait B. Dulce sabor a Brasil antiguo: perspectiva dialógica. Páginas de Guarda. Revista de lenguaje, edición y cultura escrita. 2009;7:52-66.

Brait B. Análise e teoria do discurso. In: Brait B, organizadora. Bakhtin: outros conceitos-chave. São Paulo: Contexto; 2008. p. 9-31.

Brait B. Uma perspectiva dialógica de teoria, método e análise. Gragoatá. 2006;20:47-62. [citado em 20 fev. 2015]. Disponível em: http://www.uff.br/revistagragoata/ojs/index.php/ gragoata/article/view/324/325.

Brait B. A construção do sentido: um exemplo fotográfico persuasivo. In: Lingua e literatura, n.21, 1995; p.19-27.

Brait B, Dugnani BL. Em cartaz, a cara e o corpo da linguagem das ruas. In: Brait B. Dialogismo: teoria e(m) prática. São Paulo: Terracota; 2014.

Brait B, Pistori, MHC. A produtividade do conceito de gênero discursivo em Bakhtin e o Círculo. Alfa. Revista de Linguística. São Paulo, 56 (2):371-401,2012. [citado em 22 fev. 2015]. Disponível em: http://seer.fclar.unesp.br/alfa/article/viewFile/5531/4343 
Édeline F, Klinkenberg, JM. Introduction. Revue Protée. Théories et pratiques sémiotiques. Rhétoriques du visible. 1996; 24(1). [citado em 20 fev. 2015]. Disponível em: http:// constellation.uqac.ca/2359/.

Faraco CA. Linguagem e diálogo. As ideias linguísticas do Círculo de Bakhtin. São Paulo: Parábola; 2009.

Floch JM. Semiótica plástica e linguagem publicitária. Significação. 1987;6:29-50.

Grillo SVC. Esfera e campo. In: Brait B, organizadora. Bakhtin: outros conceitos-chave. São Paulo: Contexto; 2008. p. 133-160.

Grillo SVC. Enunciados verbo-visuais na divulgação científica. Revista da ANPOLL. 2010; 27:215-243. [citado em 20 fev. 2015]. Disponível em: http://www.anpoll.org.br/revista/ index.php/revista/article/viewFile/149/159

Kress G. Multimodality. A social semiotic approach to contemporary communication. London/New York: Routledge; 2010.

Medviédev PN. O método formal nos estudos literários. Introdução crítica a uma poética sociológica. Ekaterina Vólkova Américo e Sheila Camargo Grillo, tradutoras. Sáo Paulo: Contexto; 2011.

Pistori MHC. Persuasão e eficácia discursiva no direito: modos de ser, modos de dizer. [tese] São Paulo: Universidade de São Paulo; Faculdade de Filosofia, Letras e Ciências Humanas. 2008. [citado em 14 nov. 2011]. Disponível em: http://www.teses.usp.br/teses/ disponiveis/8/8142/tde-06042009-171515/

Pistori MHC. Mikhail Bakhtin e Retórica. Um diálogo possível e produtivo. RÉTOR. 2013; 1(3):60-85. [citado em 22 jan. 2014]. Disponível em: http://www.revistaretor.org/ pdf/retor0301_pistori.pdf.

Pistori MHC. Dialogia na persuasão "publicitária". Bakhtiniana. Revista de Estudos do Discurso. 2014a;9(1):148-167. [citado em 10 mar. 2014]. Disponível em: http://revistas. pucsp.br/index.php/bakhtiniana/article/view/16717/14756

Pistori MHC. Verbo-visualidade e argumentação em discursos jurídico-processuais, $2014 \mathrm{~b}$. [citado em 10 mar. 2015]. Disponível em: http://www.unicv.edu.cv/images/ail/78Pistori. pdf.

Pistori MHC. Democracia, jornalismo e discurso jurídico: ressonâncias dialógicas e hegemonia. In: Brait B; Magalhães AS. Dialogismo: teoria e(m) prática. São Paulo: Terracota; 2014c. p. 153-170. 
Voloshinov, VN. Marxisme e philosophe du langage. Les problèmes fondamentaux de la méthode sociologique dans la science du langage. Traduite du russe par Patrick Sériot et Inna Tylkowski-Ageeva. Limoges: Lambert-Lucas; 2010.

Voloshinov, VN. Qu'est-ce que la langue et le langage? In: Voloshinov VN. Marxisme et philosophie du langage. Les problèmes fondamentaux de la méthode sociologique dans la science du langagem. Préface Patrick Sériot. Limoges: Lambert-Lucas; 2010. p. 519-563.

Recebido em: 06/04/2015

Aceito em: 15/06/2015

Pistori, M.H.C. Discurso jurídico e imagens... 